\title{
Postcolonial religious hope as stratagem to achieve political enslavement in Zimbabwe: A decoloniality approach towards an uncaptured theology of hope
}

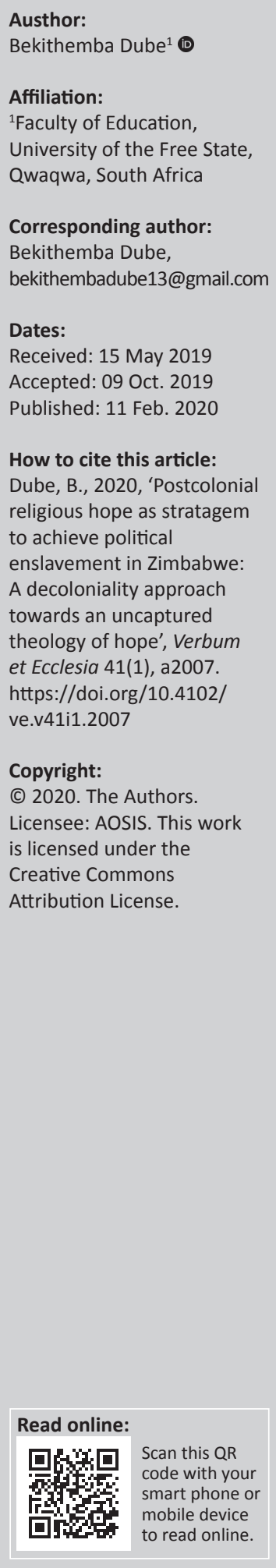

In this article, the author has shown how postcolonial religious praxis has contributed to political oppression in Zimbabwe. This is done by analysing prophetic messages of hope in the face of economic trajectories and argued that prophetic discourses have, covertly and overtly, become a stratagem for political oppression. To this end, religious leaders play a leading role in the zombification of people to accept oppression and marginalisation, thereby relegating citizens to the periphery. To develop this article, the author has analysed incidents associated with Prophets Walter Magaya and Emmanuel Makandiwa, and the Mapostori movement in Zimbabwe. The author has used decoloniality as a lens to challenge postcolonial prophetic hope that contributes to oppression. He is guided by two questions: (1) How have Magaya, Makandiwa and the Mapostori contributed to sustained political oppression whilst acting on the pretext of giving people hope? (2) What could be done for Christians to free themselves from a captured theology of hope? The author argues that religion that is premised on political ambivalence with the aim of oppressing and sustaining oppression does not deserve a place in democratic society; thus, there is a need to confront religious narratives, enact uncaptured theology and move towards the criticalisation of religious curriculum in Zimbabwe.

Intradisciplinary and/or interdisciplinary implications: This article is interdisciplinary in the sense that it touches issues such as politics, religion, sociology and education. In this article, the author has shown how all these disciplines come into play and that malfunction of religion can contribute to oppression and underdevelopment in a society.

Keywords: decoloniality; captured theology of hope; education; prophetic movements; Magaya; Makandiwa.

\section{Introduction}

Most religious leaders of the colonial period were active in the political affairs of Zimbabwe and contributed to Zimbabwe achieving independence in 1980 through upholding liberation and black theology. Amongst the prominent religious leaders who participated in the liberation were Reverend Ndabaningi Sithole, Reverend Bishop Abel Mozorewa and Canaan Banana. The mandate of these leaders was clear, namely, to see a new Zimbabwe free of oppression and characterised by a democratically elected government that reflects the aspirations of Zimbabwe's general populace. However, some postcolonial religious manifestations seem to have taken up a different narrative than that of the colonial era. Rather than being agents of social change that advocate for social justice, some religious leaders have, to the contrary, indirectly contributed to, sustained and promoted social oppression, injustice and suffering. The author does not intend to imply that religious leaders should cease their involvement in national politics (Mhandara, Manyeruke \& Hofisi 2013). Instead, his viewpoint is that their involvement should be centred in promoting democratic tendencies and fighting in the corner of the oppressed - based on the model of leadership demonstrated by Jesus Christ. The argument that this article develops is centred on the notion that politicians and their affiliations, in order to foster and sustain the structural entrenchment of poverty, have used some religious leaders, and corruption in the continent, in a number of ways (Agbiji \& Swart 2013), and one of these ways is through preaching hope.

In order to develop the argument of the article, the author has zeroed in on the prophetic movements of Magaya, Makandiwa and some African-initiated churches under the banner referred to as the Mapostori. The author argues that the aforementioned movements have played a critical and indirect role in creating a false consciousness or sense of freedom through their prophecies and discourses which have culminated in poverty, marginalisation and lack of good governance. Furthermore, the author argues that the relationship between these prophets and 
organisations, and politicians, has been rather fluid and is informed by the political environment and the benefits associated with taking certain positions at a particular time. The author problematises this in the way suggested by Cesaire (2000:32) because religious and political reciprocity is disruptive, decivilising, dehumanising and exploitative. In fact, whilst the author avoids succumbing to reductionism, it is worth noting that the upsurge of new religious movements, such as those of Magaya, Makandiwa and the Mapostori, in the context of ongoing social, political and economic ambivalence, has created more confusion than it has provided solutions for the role and effectiveness of religion under the auspices of constructing sustainable solutions for the Zimbabwean problem of use of religion for oppression (Zimunya \& Gwara 2013:191).

\section{Background of Makandiwa, Magaya and the Mapostori movements}

Emmanuel Makandiwa is a popular religious leader who founded an interdenominational church in 2008, which became a fully functional church in 2010. He used to be a pastor in the Apostolic Faith Mission in Zimbabwe (Gunda \& Machingura 2013), and now leads the United Family International Church - one of the biggest prophetic movements in Zimbabwe.

The way Walter Magaya rose to prominence is rather unclear and contested, although the underlying agreement is that he rose in conjunction with TB Joshua, who is one of the prominent prophets in Nigeria (Chitando \& Biri 2016). Magaya leads a church popularly known as Prophetic Healing and Deliverance Ministry (PHD). He was born in Mondoro, has a large following and the church's headquarters is in Waterfalls.

The Mapostori forms part of the African instituted churches, which is a group of independent Christian churches having its roots in the African continent; hence, on some platforms, these are referred to as indigenous churches (Dube 2019). Owing to members' attire, they are popularly known as white garment churches, whilst the men shave their heads and wear long beards; they are sometimes called the Masowe people (Mapuranga 2013). Having briefly explained the main players, the author now refers to the main issues of this article and situates the problem motivating it.

\section{Situating the need for an uncaptured theology of hope}

It has been argued that various trajectories have emerged in association with different prophetic movements within the political space of Zimbabwe. These trajectories have given rise to the author's argument that religion, when not problematised in the African context, could be a social pathology that promotes repression and suppression, especially in its nexus with politics. One of the trajectories that is seen in Africa, in particular, is that religion occupies a predominantly economic space, rather than serving as a space for spiritual enrichment. Elaborating on this challenge, Epondo (2015) is of the view that most churches in Africa are run like insurance companies - the so-called 'Men and Women of God' desire lavish lifestyles and see religious spaces as places for wealth accumulation. Moyo (2014) argues that in the midst of an economic crisis, Zimbabwean preachers' influence continued to grow, especially regarding their involvement in partisan political matters.

Whilst the article describes the way the theology of hope has been captured by Magaya, Makandiwa and the Mapostori, the argument is reduced to a minimalistic and biased approach unless it emphasises that the prophetic movements and the Mapostori organisation have also played a pivotal role in sustaining an arguably harmonious society despite various detrimental, political and social trajectories. In fact, they have provided comfort and a message of 'hope', which, as the author argues in this article, has benefited politicians and prophets more than the general populace. Despite appreciation for their efforts, these prophets and the Mapostori find themselves, knowingly or unwittingly, captured by a theology that promises hope that eventually contributes to the oppression of Zimbabwean people. In this light, the author agrees with Beyers (2014) that the issue of religion and its praxis need to be put on the table again for debate, and this time, according to Mpofu (2017), it is an urgent matter, especially in light of questionable postcolonial praxis of religion, which promotes oppression.

\section{Theoretical framing: Decoloniality}

To problematise the postcolonial religious space in Zimbabwe, in which religion has become a tool of oppression, as opposed to one of liberation, the author uses decoloniality theory. $\mathrm{He}$ chose decoloniality theory because the theory allows for a new way of thinking about, building and imagining a better future (Ndlovu-Gatsheni 2015:46). The theory rejects modernity, which is located on the oppressed and exploited side of the 'colonial difference', and instead argues 'towards a decolonial liberation struggle to a world beyond eurocentered modernity' (Ramón 2011:12), promoting a desire that all people, who had been earlier pushed to the periphery by colonisation and, in the more recent past, by oppressive and partisan religious movements, should be pushed into the zone of being. Thus, the decoloniality theory, in the context of oppression and dehumanisation, seeks to address injustice (Mpofu 2017). As argued by Ndlovu-Gatsheni (2013), decoloniality is a:

$[M]$ elee against invisible vampirism of imperialism technologies and colonial matrices of power (coloniality) that continue to exist in the minds, lives, languages, dreams, imaginations, religion and epistemologies of modern subjects in Africa and the entire global South. (p. 11)

Therefore, decoloniality, as argued by Mpofu (2017:4), is seen as a counter-strategy of coloniality, which aims to 'evoke a philosophy of liberation, which entails the rehumanisation of 
the dehumanised and the courage to care and to love'. The theory is ideal for underpinning this article in that it calls for resistance to religious narratives that sustain oppression, especially those contextualised in politics. Through this lens, arguing in the words of Mignolo (2009), the author evokes the need for political and prophetic epistemic delinking as alternative for (re)imagining and building a democratic, just and non-imperial Zimbabwe.

\section{Religion and politics: Captured theology of hope}

In this section, the author answers question 1, which is 'how Magaya, Makandiwa and the Mapostori have contributed to sustaining political oppression by capturing the theology of hope?' Depending on the intersection of Magaya, Makandiwa and the Mapostori, the author discusses them together and, in some cases, separately. He starts by arguing that the emergence of prophetic organisations in the public religious domain is characterised by extra-institutional expressions of religion, outside or in addition to institutional churches (Ganiel 2016). In some cases, the prophetic organisations become problematic, especially when they are entangled in, influenced by and premised on a political mandate they work to fulfil. In any case, religious leaders can easily fall prey to being used as pawns in a much bigger chess game (Mhandara et al. 2013). Because of religious entitlement premised on political power and mileage, the prophetic movement in Zimbabwe and the Mapostori movement have been seen as harbingers of hope for a better future for the people of Zimbabwe.

Prophecies and discourses point out that Zimbabwe would regain its standing as the breadbasket of Africa. For example, Makandiwa enacted hope for many followers when he prophesied the discovery of and raining down of minerals, such as gold reserves (Mufaworova 2014). He also predicted the discovery of rare type of oil (Matenga 2015); however, to date, it has not been clarified from where and when that oil would be discovered. Similarly, Magaya predicted a turnaround in the economy under the second republic (Bulawayo24.com 2018); however, today, the economy is doing even worse than in the Robert Mugabe era. These unfulfilled prophesies lead to questions about the authenticity of prophetic movements in political arena. One may argue that Magaya's promises of hope under Mnangagwa could, perhaps, be a gesture of appeasement, because Magaya was a well-known sympathiser of Grace Mugabe, who opposed the upward mobility of Mnangagwa to presidency. Thus, premised in this thinking, the author argues that the nature of prophetic movements in relation to politics in Zimbabwe is that of a liquid that takes the shape of container. In brief, Magaya, seeing hope under Mnangagwa, could have an art where prophets cross-flow in politics for reciprocal enactment (Dube \& Nkoane 2018). In this case, religion takes the shape of political container. Thus, whilst Hove and Chenzi (2017) portray Makandiwa and Magaya as enemies of the state with whom the state is dealing ruthlessly, the author of the present article views that the prophets' wealth and popularity are the result of political and prophetic engagement and have captured the theology of hope, thereby contributing to sustained oppression.

The sad issue is that congregants are left to hold onto false hope, ignorant of the fact that most prophetic movements in African states represent a political agenda for politicians' continued stay in power. Because religious leaders' promises are premised within the religious sphere, it enacts hope amongst the country's people. The author is of view that it is a false hope because even years after prophecies of prosperity, Zimbabwe is still struggling with economic recession, which means that many people continue to confront poverty and forced immigration, and they are ultimately disappointed because the better future that was promised does not realise despite prophetic declarations. Thus, cognisant of the foregoing, Ndlovu (2017) states that it is not surprising that so many Zimbabweans' hopes of an end to their problems rest on these prophets, although the questionable prophetic promises seem to be failing. In this regard, the present article's author agrees with Wafawarova (2015), who claims that the so-called prosperity gospel has the ironic effect of keeping people in poverty. When promises fail to materialise, as is the case, the followers are usually blamed for not giving enough money, or for lacking faith or patience.

In developing the explanation for the false hope promised by religious movements, the author now refers to the Mapostori movement. Some of the Mapostori movements have, over the years, sparked controversy and drama, leading to questions about the legitimacy of some of the Mapostori organisations. They have been guilty of prophesying and endorsing lifelong presidencies, which, obviously, did not materialise (Dube 2019). With the coming of the second republic, the Mapostori have resurfaced, assuming that they are representative of the people, and creating the false hope that rescue resides in politicians, leading to citizens showering religious leaders with lavish lifestyles at the expense of suffering masses. This phenomenon must be problematised through the lens of decoloniality; it must be challenged and religious adherents who long for social justice must be permitted to continue the struggle to achieve a religion that is not oppressive but premised on the values of democracy.

We cannot deny that when Mnangagwa came to power whether by coup or through legitimate means, depending on the perspective from which his ascent to power is viewed the general assumption was that a new dawn, and a new hope, had come to the people of Zimbabwe; confirmation was provided by the prophets and the Mapostori (Smith 2019). At a gathering of more than 250000 members of the church for the annual Passover at Mafararikwa Shrine, in Bocha, Marange, the leader, Mutumwa Noah Taguta, endorsed Mnangagwa as the country's new leader, who would bring a better Zimbabwe; this endorsement was confirmed by more than six evangelists (NewsBeezer 2018). The author believes that congregants saw the utterance as a 
confirmation of a new future, and it was all the more believable because it was endorsed by church leaders. One of the Mapostori church leaders stated:

You can now even go and stop campaigning because you already have the trophy. There is nothing that this man says that will not come to pass and there is a better future. (NewZimbabwe. com 2018)

However, despite this endorsement, the country's economy and people's lifestyles have gone from bad to worse, raising questions about this prophetic utterance, which seems to have taken Zimbabwe to the periphery of development compared to other postcolonial states, such as South Africa.

Therefore, the author argues that in Zimbabwe the theology of hope has been captured by a deliberate political strategem that benefits religious leaders and politicians at the expense of general populace. Most of the populace does not seem to see these trends as a problem - Quijano (2008:182) calls it 'a mental category of modernity', which strives to ensure coloniality, as proposed by Walsh (2007:79), '[t]hrough strategies of manipulation, co-optation, division, and control'. Thus, through the lens of decoloniality, there is a need for a religion that evokes and challenges such a nexus (of politics and religion), especially when religion undermines the quest for a better life for the people of Zimbabwe. Prophets do not seem to realise that once politicians have achieved their mandate, they no longer need these prophets, and the politicians are likely to abandon them. This happened to Nobert Kunonga, the former leader of the Anglican Church, diocese of Harare (Muzulu 2107; Sheers 2011).

\section{Bond notes and prophetic inventions}

In 2016, Zimbabwe started to transfer its currency slowly from US dollar (USD) to bond notes. This move was resisted by many civic organisations (Chutel 2016; Mpofu 2015; Southall 2017). This resistance led to the rise of political activists, such as Evans Mawarire (Sharara 2016); former vice president of Zimbabwe, Dr Joyce Mujuru, even took the government to court over the bond notes (Mugove 2016). Evans Mawarire and Joyce Mujuru, amongst many others, argued that bond notes are unsustainable because they are not backed by industry or other economic factors; hence, it was necessary to continue using USD or to institute a multicurrency system. In the dilemma of bond issue, and in the face of anger, resistance and a clearly bleak vision of an economic turnaround, Prophets Magaya and Makandiwa emerged as harbingers of new hope, who supported the introduction of bond notes.

Initially, Makandiwa, like many other Zimbabweans, opposed bond notes. This led to Ndanga, the former president of the Mapostori movement, to say that Makandiwa, who 'refused the bond notes clearly stated that he doesn't trust the Reserve Bank Governor (Dr John Mangudya) even if what he has planned makes sense' (ZimEye.com 2016). This statement confirms Makandiwa's earlier direct resistance. However, not many people know why he suddenly changed his stance on bond notes (Kells 2016; Mabehla 2016). During one of his judgement nights, Makandiwa argued that God would bless Zimbabwe if it used its own currency, namely, the bond notes (Kells 2016). Like Makandiwa, Magaya initially opposed the use of bond notes and foretold national demonstrations opposing the introduction of bond notes (Masara 2016). However, like Makandiwa, Magaya had a change of heart inrelation to bond notes. Chaya and Muguwu (2016:1) report Magaya saying: '[a]fter I met Governor Magudya, I realise that bond notes are the right direction'. This statement was not received well by some advocacy groups, such as the one led by Themba Mliswa, whom Musaka (2016) quotes as saying:

Magaya is not an economist and must not act like an economist. In fact, if there is anything, I think you [Magaya] are fleecing people's money in an economy where things are tough. And now you want to tell us how great the bond notes arewhen you are stealing people's money everyday. (n.p.)

The Mapostori movements did not find it difficult to accept bond notes, as it is argued that they are the foot soldiers of the ruling party (Masara 2016; ZimEye.net 2016). In support of this observation, Tutani (2017) points out that, 'invariably these Vapostori leaders have been religious enablers of repression'. This approach undermines the observation by Powell and Clarke (2012:15) that postcolonial religions have the notion that religious leaders are superheroes and custodians of absolute truth.

Considering the above, the prophetic movements that served as harbingers of new hope through bond notes weakened the resistance the people of Zimbabwe had to bond notes. The present author views that, as the prophets have such an influence on people's lives, it was easy to convince them to accept bond notes, despite its obvious likelihood of failure. The failure is buttressed further by Magezi and Banda (2017), who note that Pentecostal prophets impose themselves as super-spiritual authorities who must be relied upon by believers, in addition to Christ. Consequently, the author argues that prophetic figures present coloniality of power, which is sustained by asymmetrical power relations and conceptions of humanity through racial, gender, sex, religious and ethnic hierarchisation (Ndlovu-Gatsheni 2013:11).

Through this type of influence, religious figures and discourses play a pivotal role in ensuring acceptance or rejection of political ideologies. Unfortunately, as a result of this influence peddling, congregants and the nation at large suffer. It is an open secret that bond notes have failed to revive the economy, despite assurances by prophets that all is well. Informed by decoloniality, we know that religion has been used as a stratagem for political oppression in most colonial states of Africa. Thus, there is a need to evoke a religion that questions and requires authenticity from religious figures. If religion continues on this path, Africa will continue to exist in poverty, guided by prophets who 
forge alliances with politicians at the expense of maintaining their divine mandate to ensure that religion contributes to sustainable development.

\section{Undoing captured theology of hope in Zimbabwe}

In this section, the author responds to the second research question: what should be done for Christians to free themselves from captured theology of hope? The section is critical, especially amongst decoloniality scholars, whose agenda is outlined by Alvesson (1992), that is, to contribute to

[F]reeing individuals and groups from suppressive social and ideological situations, particularly those that place socially unnecessary precincts upon development and enunciation of human consciousness. (p. 432)

Thus, the author argues that the nature and praxis of religion in some postcolonial states present serious trajectories that contribute indirectly to sustaining poverty and suffering. Once people put their confidence in prophetic movements, such as the Mapostori, especially those infiltrated by political alliances, it is likely that the Mapostori's participation in society remains questionable, and even undesirable. Religious scholars who are committed to social justice must continue to tease and unmute discourse aimed at reinventing an uncaptured theology, which has the potential to contribute to democracy, accountability and sustainable development. The author concurs with Ndlovu-Gatsheni (2013) that:

$[W]$ hat African people must be vigilant against is the trap of ending up normalising and universalising [religion as stratagem political oppression] as a natural state of the world, however, it must be unmasked, resisted and destroyed because it produces a world order that can only be sustained through a combination of violence, deceit, hypocrisy and lies. (p. 10)

Cognisant of the above discussion, the author proposes two solutions. Firstly, he discusses the uncaptured theology of hope.

\section{Inventing an uncaptured theology of hope}

It is abundantly clear that there is a need to rethink the praxis of theology in Africa, especially within the emerging prophetic ministry, which appears to have departed from orthodox and conventional theology. The author does not say that the invention of new ways of doing theology is wrong, undesirable and undoable, but when such an invention slides into questionable practices characterised by oppression, abuse and mafia tendencies, it requires serious thinking amongst those who long for a better Zimbabwe. Thus, in this context, scholars committed to social justice and democracy must start to question, tease and evoke a new way of thinking that can undo harmful trajectories that emerge from prophetic movements. The thrust of this article is to move towards a need to create a new theology that attempts to 'awaken of consciousness and awareness of social injustices, motivating self-empowerment and social transformation' (Stinson 2009:506). It is clear that few Africans have applied themselves sufficiently to thinking critically about what they do within religious circles; instead, they follow all practices proposed to them, thus pushing the African continent to the periphery of development. As indicated above, prophets are seldom questioned, even if their demands or statements are clearly contrary to what is expected, just and acceptable. Because of the prophets' influence, some have aligned themselves with politicians to promote their political agenda, thereby moving towards a terrain of oppression. Nevertheless, many religious adherents fall victim to prophetic movements, only to realise later that their constitutional rights and democracy, in general, have been violated by promises of false hope. The author strongly argues that if Zimbabweans had applied themselves to critiquing the prophetic movements and had resisted these questionable narratives, there is a possibility that some of the harmful trajectories, such as bond notes, could have been avoided and, perhaps, the economy could have achieved stability. Unfortunately, resistance disappeared once prophets expressed their support to bond notes and persuaded people to believe that God supports the currency. If God had, indeed, confirmed support to this currency, then why is Zimbabwe still sliding to recession today? Sanni (2016:12) answers the question partly by affirming that the problem in Africa is that we have given unquestionable power to religious leaders; thus, the challenge is to reclaim the power and distribute it to all to ensure sustainable development.

It is at this juncture that the present author argues that religious discourses must move away from captured theology towards a theology that breaks away from narrow ways of thinking about colonial relations, in order to accomplish the unfinished and incomplete 20th-century dream of decolonisation (Ramón 2011). The present argument is informed by decoloniality, which states that there is a need for an uncaptured theology that will 'evoke a philosophy of liberation that entails the rehumanisation of the dehumanised and the courage to care and to love' (Mpofu 2017:4). Through an uncaptured theology of hope, Zimbabweans can enter a terrain that 'dismantles relations of power and conceptions of knowledge that foment the reproduction of racial, gender [political-religious oppression] and geo-political hierarchies' (Maldonado-Torres 2007:243). In addition, as suggested by Ramón (2011:7), this will give rise to a geopolitics of knowledge based on 'critical decolonial thinking emerging as a critique of modernity towards a pluriversal transmodern world of multiple and diverse ethico-political projects in which a real horizontal dialogue and communication', as opposed to accepting prophetic discourses and prophecies, without subjecting them into critical thinking.

This uncaptured theology of hope supports a better future, whether prophetical or not, on condition that issues of social justice, accountability, democracy and transparency are significant characteristics of the church and the government. Then we can talk about a better and more beautiful country that is blessed by God, and move to regain for Zimbabwe the status of the breadbasket of Africa. The author concludes this 
point by arguing that Zimbabwe cannot afford to slide into poverty further because of mismanagement and corruption, especially not as a result of religion being used to endorse this collapse through reciprocal relationships between prophets, the Mapostori and politicians. There is a need for resistance against the capture of the theology of hope.

\section{Criticalisation of religion in schools}

Education is key to any success achieved by any nation. Through education, citizens are empowered and able to contribute to sustainable development. Religious study is one of the school subjects that could be placed to usher empowerment and sustainable development. However, this could only happen if religious discourses are not memorised, and do not involve a mere call of morality, without interrogating the motive behind such a call. According to the Ministry of Primary and Secondary Education (2015:3), religious, family and moral education are the goals of the study of religion in Zimbabwe, that is gaining an 'understanding of the processes of a free society, and heightening awareness of the importance of character development to the continued success, peace and stability of the Zimbabwean society'. Whilst the values are true, desirable and applauded for any country, they become a problem when they lead to oppression of people as a result of calls for docility and uncritical thinking, and fails to question beliefs. The present article's author is of the view that Zimbabwe needs a religious education that empowers learners to question all prophets and the Mapostori to promote accountability and the promotion of human rights and democracy. Unfortunately, this approach to religious education is absent; hence, some prophetic movements and the Mapostori continue to contribute to social injustice knowingly or unknowingly.

In essence, the author calls for the criticalisation of religion in schools so that learners can use case studies of religious praxis and discourse which they critique in light of democracy and goals of social justice. Through such an approach, the curriculum could evoke intellectual extraversion and epistemic dependence (Ndlovu-Gatsheni 2016), which would be conceptual and empirical (Narayanan 2016:151). Thus, informed by decoloniality, the author agrees with Sithole (2014) that there is a need to rethink, and even to go beyond thinking, to the point of exhaustion, to avoid coloniality of mind, especially when religion has premised the space of curriculum. In addition, criticalisation of religion can move towards denaturalisation of modern religious powers, and the inclusion of non-modern systems and principles of knowledge, voices and categories of thought (Snyman 2014:1036). This is not a call for a fundamentalist or nationalist solution to the persistence of coloniality; instead, it is a call for critical decolonial thinking, as the strategy or mechanism to achieve a 'decolonialized transmodern world' (Ramón 2011:3) that values lives, democracy and justice. The author opines that religious education must start to confront issues of social injustice, lack of democracy and the issues that have been sugar-coated with religion.

\section{Conclusion}

No nation can strive beyond the integrity of its leaders; thus, it is critical that issues of leadership, especially within religious circles, are discussed and problematised, especially if religious leaders contribute to oppression knowingly and unknowingly. In this article, it is shown how the capture of the theology of hope can contribute to sustaining oppression in postcolonial states. In doing so, Zimbabwe is used as a case study, with special reference to the prophets Magaya and Makandiwa, and the Mapostori. The positive achievements of these prophets and movements are not discredited, but the other side is shown, that is, how their narratives have become part of a bigger chase game to sustain oppression in Zimbabwe. The author concludes by arguing that decoloniality calls us to be vigilant for any form of injustice that seeks to produce a world order that is sustained by oppression, false hope and lack of accountability. Through decoloniality, religion enters a terrain that strives to achieve equality for all, and an uncaptured theology of hope can assist us in this regard.

\section{Acknowledgements Competing interests}

The author has declared that no competing interests exist.

\section{Authors' contributions}

The author declares that he is the sole author of this research article.

\section{Ethical considerations}

This article followed all ethical standards for a research without direct contact with human or animal subjects.

\section{Funding information}

This research received no specific grant from any funding agency in the public, commercial or not-for-profit sectors.

\section{Data availability statement}

Data sharing is not applicable to this article as no new data were created or analysed in this study.

\section{Disclaimer}

The views and opinions expressed in this article are those of the author and do not necessarily reflect the official policy or position of any affiliated agency or the University of the Free State.

\section{References}

Agbiji, O.M. \& Swart, I., 2013, 'Historical sources of Christian religious leadership ideology: Implications and challenges for social transformation in post-military Nigeria', Studia Historiae Ecclesiasticae XXXIX(1), 221-246.

Alvesson, M., 1992, 'On the idea of emancipation, management and organization studies', Academic of Management Review 17(3), 432-454. https://doi.org/10.5465/ amr.1992.4281977 
Beyers, J., 2014, 'The church and the secular: The effect of post-secular on Christianity', HTS Teologiese Studies/Theological Studies 70(1), 1-12. https://doi.org/10.4102/ HTS Teologiese
hts.v70i1.2605

Bulawayo24.com, 2018, 'Prophet Magaya predicts economic rebound under Mnangagwa', Bulawayo24 News, 03 January, viewed 15 April 2019, from www. bulawayo24.com/prophets-magaya-predicts-economic-rebound-undermnanggwa.

Cesaire, A., 2000, Discourse on colonialism, transl. J. Pinkham, Monthly Review Press, New York.

Chaya, V. \& Maguwu, S., 2016, 'Magaya meets Magudya over bond notes', DailyNews, 27 May, viewed 01 March 2019, from www.dailynews.co.zw/articles/2016/05/27/ magaya-meets-magudya-over-bond-notes.

Chitando, E. \& Biri, K., 2016, 'Walter Magaya's prophetic healing and deliverance (PHD) ministries and pentocostalism in Zimbabwe: A preliminary study with particular reference to ecumenism', Studies Historiae Ecclesssiasticae 42(2), 72-85. https://doi.org/10.17159/2412-4265/2016/829

Chutel, L., 2016, 'Zimbabwe zombie bond notes are only good for bribes and stimulating anxiety', Quartz Africa, 28 November, viewed 17 January 2019, from https://qz.com/africa/846897/zimbabwes-zombie-bond-notes-are-only-goodfor-bribes-and-stimulating-anxiety/.

Dube, B., 2019, 'What about the Vapostori now? The ambivalence of politics of relevance among indigenous churches in Zimbabwe', HTS Teologiese Studies/ Theological Studies 75(1), a5202. https://doi.org/10.4102/hts.v75i1.5202

Dube, B. \& Nkoane, M.M., 2018, 'The interface of politics and religion in Zimbabwe: Rethinking religious leaders as agents of enthronement and displacement',
Alternation (Special Edition) 23(2018), 224-243. https://doi.org/10.29086/2519Alternation (Special Edit
$5476 / 2018 / \mathrm{sp} 23 a 10$

Epondo, P.T., 2015, “'Con” pastors strive as Africans become increasingly desperate for miracles', Voices of Africa, 23 July, viewed 21 September 2018, from https:// voicesofafrica.co.za/con-pastors-thrive-africans-become-increasingly-desperatemiracles/.

Ganiel, G., 2016, Transforming post-Catholic Ireland: Religious practice in late modernity, Oxford University Press, Oxford.

Gunda, M.R. \& Machingura, F., 2013, 'The "Man of God". Understanding biblical influence on contemporary megachurch prophets in Zimbabwe', in E. Chitando, M.R. Gunda \& J. Kügler (eds.), Prophets, profits and the Biblein Zimbabwe Festschrift for Aynos Masotcha Moyo, pp. 15-27, University of Bamberg Press, Bamberg.

Hove, M. \& Chenzi, V., 2017, 'Prophets of doom. The Zimbabwean Christian community and contemporary politics', Insight on Africa 9(2), 173-195. https:// doi.org/10.1177/0975087817710054

Kells, C., 2016, 'Prophet Makandiwa: I back bond notes', SA Breaking News, 28 August, viewed 12 September 2018, from www.zimmetro.com/makandiwa-bond-notes/.

Mabehla, A., 2016, 'Zim needs own currency: Makandiwa', Daily News, 28 August, viewed 12 February 2019, from www.dailynews.co.za/2016/08/28/zim-nnedsown-currency-makandiwa.

Magezi, V. \& Banda, C., 2017, 'Competing with Christ? A critical Christological analysis of the reliance on Pentecostal prophets in Zimbabwe', In die Skriflig 51(2), 1-8. https://doi.org/10.4102/ids.v51i2.2273

Maldonado-Torres, N., 2007, 'On coloniality of being: Contributions to the development of a concept', Cultural Studies 21(2-3), 243. https://doi.org/ 10.1080/09502380601162548

Mapuranga, T.P., 2013, 'AICs as a gendered space in Harare, Zimbabwe: Revisiting the role and place of women', Studia Historiae Ecclesiaticae 39(2), 303-317.

Masara, W., 2016, 'Bond notes split church', The Chronicle, 17 August, viewed 22 December 2018, from www.chronicle.co.zw/bond-notes-split-church.

Matenga, M., 2015, 'Makandiwa prophecies oil reserves in Zim', The Standard, 30 August, viewed 20 February 2019, from www.thestandard.co.zw/2015/08/30/ marketing-prophecies-oil-reserves-in-zim.

Mhandara, L., Manyeruke, C. \& Hofisi, S., 2013, 'The church and political transition in Zimbabwe: The inclusive government context', Journal of Public Administration Zimbabwe: The inclusive government context', Journal of Public
and Governance 3(1), 10. https://doi.org/10.5296/jpag.v3i1.3379

Mignolo, W.D., 2009, 'Epistemic disobedience, independent thought and de-colonial freedom', Theory, Culture \& Society 26(7-8), 1-23. https://doi.org/10.1177/ 0263276409349275

Ministry of Primary and Secondary Education, 2015, Religious, family and moral education, Curriculum Development Unit, Harare.

Moyo, J., 2014, 'In Zimbabwe, preaching is politics', Mail \& Guardian, 03 October viewed 22 February 2019, from https://mg.co.za/article/2014-10-03-inzimbabwe-preaching-is-politics.

Mpofu, S., 2015, 'The theological dilemma visa vis the moral options for relevant and practical ministry today. Lessons for the Zimbabwe council of church', Studia Historiae Ecclessiasticae 4(1), 67-85. https://doi.org/10.25159/2412-4265/99

Mpofu, W., 2017, Decoloniality as travelling theory: Or what decoloniality is not, Wits Institute for Social and Economic Research Seminar, 07 August 2017, University of the Witwatersrand, Johannesburg.

Mufaworova, R., 2014, 'Thwarting political religious cultism', Herald, 05 May, viewed 22 December 2018, from www.herald.co.za/thwarting-political-religiousviewed 22
Mugove, T., 2016, 'Mujuru sues government over bond notes', Dailynews Live, 01 August, viewed 12 February 2019, from www.dailynews.co.zw/articles/ 2016/08/01/mujuru-sues-government-over-bond-notes.

Musaka, A., 2016, 'You are not an economist, Mliswa tells Magaya', The Observer, 04 July, viewed 10 February 2017, from https://theobserver.co.zw/you-are-notan-economist-mliswa-tells-magaya/.

Muzulu, P., 2017, 'Excommunicated Anglican bishop Kunonga loses property', Newsday, 22 June, viewed 12 February 2019, from https://www.newsday.co.zw/2017/06/ excommunicated-anglican-bishop-kunonga-loses-property/.

Narayanan, Y., 2016, 'Religion, sustainable development and policy', Principles to Practices. Sustainable Development 24(2016), 149-153. https://doi.org/10.1002/ sd.1616

Ndlovu, R., 2017, 'Zimbabwe's prophets of boom promise a change of fortune', Timeslive, 01 August, viewed 10 January 2019, from www.timeslive.co.za/sundaytimes/business/2017-01-08/zims-prophets-of-boom-promise-a-change-offortune.

Ndlovu-Gatsheni, S.J., 2013, 'Why decoloniality in the 21st century', The Thinker for Thought Leaders 2013(48), 10-16.

Ndlovu-Gatsheni, S.J., 2015, 'Decoloniality in Africa. A continuing search for a new world order', Australian Review of African Studies 36(2), 22-50.

Ndlovu-Gatsheni, S.J., 2016, 'The dynamics of epistemological decolonisation in the 21st century: Towards epistemic freedom', Strategic Review for Southern Africa 40(1), 16-45.

NewsBeezer, 2018, 'Johanne Marange Apostolic Church predicts Mnangagwa victory', NewsBeezer, viewed 28 January 2019, from www.newsbeezer.com/zimbreeder. com/zimbabwe/johanne-marange-apostolic-church-predicts-mnangagwavictory.

NewZimbabwe.com, 2018, 'Vapostori say Mnangagwa has already won elections; Grace Mugabe warning', New Zimbabwe, 15 July, viewed 22 January 2019, from https://www.newzimbabwe.com/vapostori-say-mnangagwa-has-already-wonelections-grace-mugabe-warning/.

Powell, R. \& Clarke, S., 2012, 'Religion as an evolutionary by-product: A critique of the standard model', Britain Journal Philosophy of Science 63, 457-486. https://doi. org/10.1093/bjps/axr035

Quijano, A., 2008, 'Coloniality of power, Eurocentrism and Latin America', Nepantla $1(3), 533-580$

Ramón, G., 2011, 'Decolonizing post-colonial studies and paradigms of political economy. Transmodernity, decolonial thinking and global coloniality', economy. Transmodernity, decolonial thinking and global coloniality',
Transmodernity: Journal of Peripheral Cultural Production of the Luso-Hispanic Transmodernity: Jour

Sanni, J.S., 2016, 'Religion: A new struggle for African identity', Phronimon 17(2), 1-13. https://doi.org/10.17159/2413-3086/2016/120

Sharara, M., 2016, 'Bond notes could provide Mugabe's much-needed end game', Fin24, 13 October, viewed 27 January 2019, from www.fin24.com/opinion/bondnotes-could-provide-mugabes-much-needed-end-game.

Sheers, O., 2011, 'The illegal seizure by excommunicated Bishop Nolbert Kunonga of the Arthur Shearly Cripps Shrine in Chivhu, Zimbabwe', Statement by Owen Sheers, Solidarity Peace Trust website, viewed 13 January 2019, from http:// solidaritypeacetrust.org/1087/the-illegal-seizure-by-excommunicated-bishopnolbert-kunonga-of-the-arthur-shearly-cripps-shrine-in-chivhu-zimbabwe/.

Sithole, T., 2014, 'Achille Mbembe: Subject, subjection, and subjectivity', PhD thesis, University of South Africa, Pretoria.

Smith, C., 2019, 'Zimbabwe's toxic culture of leadership in an entanglement of politics, military and state', Op-ed, Daily Maverick, 18 February, viewed 12 February 2019, from www.dailymaverick.co.za/article-culture-of-leadership-in-an-antanglementof-politics-military-schools-state.

Snyman, G.F., 2014, 'Esther and African Biblical Hermeneutics: A decolonial inquiry', Old Testament Essays 27(3), 1035-1061.

Southall, R.J., 2017, 'Bond notes, borrowing, and heading for bust: Zimbabwe's persistent crisis', Canadian Journal of African Studies/Revue Canadienne des études persistent crisis', Canadian Journal of African Studies/Revue Canadienne des etud
Africaines 51(3), 389-405. https://doi.org/10.1080/00083968.2017.1411285

Stinson, D.W., 2009, 'The proliferation of theoretical paradigms quandary. How one novice researcher used eclecticism as a solution?', The Qualitative Researcher 14(3), 498-523.

Tutani, C., 2017, 'Christians should not follow blindly like sheep', NewsDay Zimbabwe, 27 October, viewed 12 March 2019, from www.newsday.co.zw/christians/should/ not/follow/blindly/like/sheep.

Wafawarova, R., 2015, 'The curse of prosperity gospel', The Herald, 15 February, viewed 23 December 2018, from https://www.herald.co.zw/the-curse-ofprosperity-gospel/.

Walsh, C., 2007, 'Shifting the geopolitics of critical knowledges: Decolonial thought and cultural studies "others" in the Andes', Cultural Studies 21(2-3), 224-239. https://doi.org/10.1080/09502380601162530

ZimEye.net, 2016, 'Makandiwa performs shock U-turn, starts backing bond notes', ZimEye, 28 August, viewed 13 January 2019, from http://www.zimeye.net/u-turnas-makandiwa-backs-bond-notes/.

Zimunya, C.T. \& Gwara, J., 2013, 'Pentecostalism, prophets and the distressing Zimbabwean milieu', in E. Chitando, M.R. Gunda \& J. Kügler (eds.), Prophets, profits and the Bible in Zimbabwe, pp. 16-40. University of Bamberg Press, Bamberg. 